\title{
MORPHOLOGY OF HUMAN NUCLEUS ACCUMBENS NEURONS BASED ON THE IMMUNOHISTOCHEMICAL EXPRESSION OF GAD67
}

Maja Sazdanovic ${ }^{1}$, Slobodanka Mitrovic ${ }^{3}$, Milos Todorovic ${ }^{2}$, Maja Vulovic ${ }^{2}$, Dejan Jeremic ${ }^{2}$, Zoran Milosavljevic ${ }^{1}$, Predrag Sazdanovic ${ }^{2}$, Neda Ognjanovic ${ }^{2}$ ${ }^{1}$ Department of Histology and Embryology, Faculty of Medical Sciences, University of Kragujevac, Serbia ${ }^{2}$ Department of Anatomy and Forensic medicine, Faculty of Medical Sciences, University of Kragujevac, Serbia

${ }^{3}$ Department of Pathological Anatomy, Faculty of Medical Sciences, University of Kragujevac, Serbia

\section{MORFOLOGIJA NEURONA HUMANOG NUIKLUSA AIUMBENSA ZASNOVANA NA IMUNOHISTOHEMIJSKOJ EKSPRESIJI GAD67}

Maja Sazdanovic ${ }^{1}$, Slobodanka Mitrovic ${ }^{3}$, Milos Todorovic ${ }^{2}$, Maja Vulovic ${ }^{2}$, Dejan Jeremic ${ }^{2}$, Zoran Milosavljevic ${ }^{1}$, Predrag Sazdanovic ${ }^{2}$ i Neda Ognjanovic ${ }^{1}$ Katerdra za histologiju i embriologiju, Fakultet Medicinskih nauka, Univerzitet u Kragujevcu, Srbija ${ }^{2}$ Katedra za anatomiju i sudsku medicinu, Fakultet Medicinskih nauka, Univerzitet u Kragujevcu, Srbija

${ }^{3}$ Katedra za patološku anatomiju, Fakultet Medicinskih nauka, Univerzitet u Kragujevcu, Srbija

Received / Primljen: 30.03.2016.

Accepted / Prihvaćen: 19.05.2016.

\section{ABSTRACT}

The nucleus accumbens is a part of the ventral striatum along with the caudate nucleus and putamen. The role of the human nucleus accumbens in drug addiction and other psychiatric disorders is of great importance. The aim of this study was to characterize medium spiny neurons in the nucleus accumbens according to the immunohistochemical expression of GAD67.

This study was conducted on twenty human brains of both sexes between the ages of 20 and 75 . The expression of GAD67 was assessed immunohistochemically, and the characterization of the neurons was based on the shape and size of the soma and the number of impregnated primary dendrites.

We showed that neurons of the human nucleus accumbens expressed GAD67 in the neuron soma and in the primary dendrites. An analysis of the cell body morphology revealed the following four different types of neurons: fusiform neurons, fusiform neurons with lateral dendrites, pyramidal neurons and multipolar neurons.

An immunohistochemical analysis showed a strong GAD67 expression in GABAergic medium spiny neurons, which could be classified into four different types, and these neurons morphologically correlated with those described by the Golgi study.

Keywords: nucleus accumbens; GAD67; immunohistochemistry

\section{SAŽETAK}

Nukleus akumbens je jedro koje predstavlja deo ventralnog strijatuma, zajedno sa nukleusom kaudatusom i putamenom. Ima značajnu ulogu u nastanku bolesti zavisnosti $i$ drugih psihijatrijskih poremećaja. Cilj ove studije je tipizacija GABAergičkih neurona srednje veličine sa spinama na osnovu imunohistohemijske ekspresije GAD67.

Istraživanje smo izveli na 20 humanih mozgova, oba pola, starosti od 20 do 75 godina. Ekspresija GAD67 jeuradena imunohistohemijskom metodom, a tipizacija neurona srednje veličine sa spinama je izvršena na osnovu oblika $i$ velicine some i broja impregnisanih primarnih dendrita.

Ovim istraživanjem smo pokazali da neuroni srednje veličine sa spinama u humanom nukleusu akumbensu eksprimiraju GAD67 u citoplazmi neurona, kao i u primarnim dendritima. Analizom morfologije perikariona utvdili smo prisustvo četiri tipa neurona:fuziformni neuroni, fuziformni sa bočnim dendritom, piramidalni neuroni i multipolarni neuroni.

Ovom metodologijom smo potvrdili jaku ekspresiju GAD67 u GABAergičkim neuronima srednje veličine sa spinama, koji se mogu klasifikovati u četiri morfološka tipa, što korelira sa rezultatima prethodno sprovedene Goldži studije.

Ključne reči: nukleus akumbens; GAD67; imunohistohemija

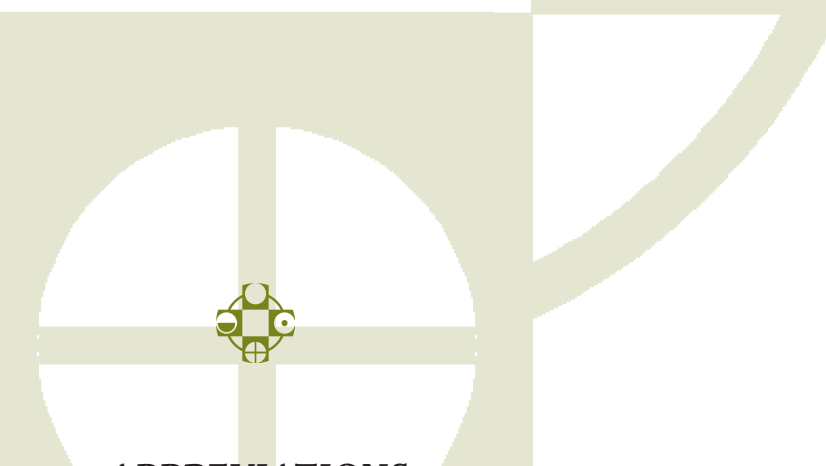

GABA - gamma-Aminobutyric acid GAD67 - glutamate decarboxylase 


\section{INTRODUCTION}

The nucleus accumbens is an important region of the brain that is involved in many reward-conditioned behaviours. As a part of the limbic system, this nucleus is positioned between the rostral part of the striatum and the lateral borders of the septal nuclei in the human telencephalon. The nucleus accumbens, in mammals, is sparsely integrated with the lateral striatum (1). The striatum is the main location of the basal ganglia and the subcortical brain region that plays a key role in active control, learning and memory (2). In mammals, based on morphological, histological and immunohistochemical criteria, the nucleus accumbens comprises several subterritories, of which two of the main parts are defined as the core and the shell (3-5). The nucleus accumbens plays a very important role in motivation and planned motor activities related to food and drug reward, sexual arousal and stress response (6-7). Dysfunction of this structure causes various mental disorders, such as obsessive-compulsive disorder, depression and drug addiction (8-10).

GABA is one of the most common neurotransmitters in the CNS, and it plays a key role in motion processes, neurogenesis and the development of tissue. Almost 95\% of neurons in the nucleus accumbens are GABAergic neurons, and the remainder are cholinergic interneurons. The GABAergic neurons of the nucleus accumbens are identified as medium spiny neurons (11). GABA is the major inhibitory neurotransmitter in invertebrates and vertebrates. GABAergic neurons form the efferent output projections from the nucleus accumbens core and shell. Defects in the regulation of GABA homeostasis cause neurological disorders, such as epilepsy, Parkinson's disease, schizophrenia, anxiety disorders, autism, bipolar disorder and post-traumatic syndrome (12-18). Glutamate decarboxylase (GAD) catalyses the production of GABA molecules, which, in comparison with any other inhibitory neurotransmitters, are widespread in the vertebrate brain. There are two forms of GAD, GAD65 and GAD67, with enzymatic characteristics and a subcellular distribution stimulated by the two genes (19).

Using antiserum specific to GAD67 and monoclonal antibodies specific to GAD65, it was shown that the two forms of GAD differ in distribution. GAD67 is widely distributed in the soma and primary dendrites of neurons, while GAD65 is primarily distributed in the axon endings of neurons in the animal brain (20-22).

Generally, in the striatum, there are several specific morphological types of neurons, which are classified by the size of the cell body (large vs. medium) and the presence or absence of spines. The most common and well-studied type of neurons in mice and rats are GABAergic medium spiny neurons (23-24). Due to the small number of studies on the human nucleus accumbens and the enormous importance of GABAergic medium spiny neurons, this study aimed to investigate this cell population and classify it based on the shape and size of the cell bodies by using the immunohistochemical expression of GAD67.

\section{MATERIAL AND METHODS}

The study included 20 adult human brains of both genders ( 11 males and 9 females) between the ages of 20 and 75 years (average $36.7 \pm 2.4$ ). All of the brains were obtained within 12-18 hours after death. Only normal brains with no visible malformations and without any neuropathological changes or neuropsychiatric history were used. The brains were fixed in $10 \%$ neutral phosphate buffered formalin (3.7\% formaldehyde) over a period of at least 3 months.

We investigated all parts of the nucleus accumbens and sliced the brain tissue in coronal sections rostrocaudally, where this nucleus merges without a clear border with the medial septal nucleus dorsomedially and ventrolaterally with the basal nucleus and substantia innominata.

The standard streptavidin-biotin-peroxidase complex method was used for the immunohistochemical analysis, according to the manufacturer's instructions (Dako, $\mathrm{LSAB}+{ }^{\circ}$ system). Serial sections 3-5 $\mu \mathrm{m}$ thick, obtained from paraffin tissue blocks of 40 hemispheres, were deparaffinized in xylene and rehydrated in graded alcohol, and the endogenous peroxidase activity was blocked. Antigen retrieval was achieved using a microwave oven at $750 \mathrm{~W}, 3$ times for 6 minutes in a high $\mathrm{pH}$ citrate buffer.

Immunostaining of GAD67 was performed with a monoclonal anti-glutamic acid decarboxylase 67 antibody (clone K-87, purified mouse immunoglobulin, product number G5419, at a dilution of 1:500, SIGMA, USA). The slides were incubated in the primary antibody for $60 \mathrm{~min}$, in a secondary antibody for $30 \mathrm{~min}$ and finally in streptavidin-HRP for 20 minutes. The visualization was performed with 3,3'-diaminobenzidine as the chromogen, and the slides were counterstained with Mayer's haematoxylin. The addition of all of the reagents, except the primary antibody, was used as the negative control.

A positive reaction for GAD67 was defined as a discrete or strong localization of the brown chromogen in the cytoplasm. The classification of the immunohistochemically impregnated neurons was performed according to the shape and size of the cell bodies and the number of impregnated primary dendrites. The morphometrical analysis involved the following two parameters: the maximal (Dmax) and minimal (Dmin) diameter of the pericarion. The criteria for the selection of the neurons for the analysis were a full appearance of the cell body and a clearly visible nucleus. The measurements of the neurons were performed using a Zeiss AxioVision 3.0.6. Three researchers assessed all of the slides independently. The results are presented as the mean \pm standard deviation.

\section{RESULTS}

GAD67 expression in the nucleus accumbens was diffusely spread in a large number of neurons, their soma and their primary dendrites, with a granular appearance and a high intensity (Fig. 1). We were able to distinguish the fol- 

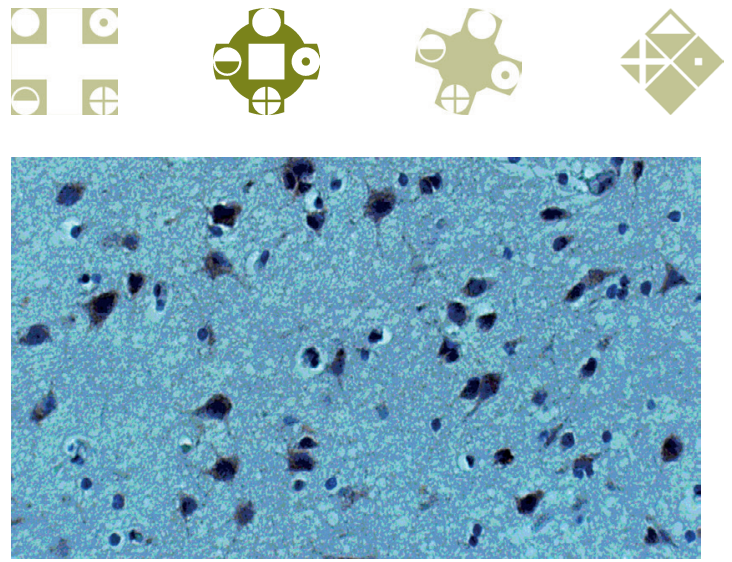

Fig. 1. The expression of GAD67 in medium spiny neurons of the human nucleus accumbens, $x 200$ magnification

lowing four types of human nucleus accumbens neurons according to the shape of the soma and the number of primary dendrites: fusiform neurons, fusiform neurons with lateral dendrites, pyramidal neurons and multipolar neurons.

\section{Type I - Fusiform neurons}

In the fusiform type of neurons, there was a strong immunoreactive expression of GAD67 in the elongated (spindle) soma, which had thick primary dendrites at both ends. The neuronal cytoplasm was filled with brown granules that partially covered the nucleus and showed a high intensity of GAD67 immunohistochemical expression. This type of neuron was observed in the shell of the nuclei. The dimensions of this type of soma are as follows: Dmax 23.02 $\pm 3.12 \mu \mathrm{m}$ and Dmin $10.8 \pm 0.94 \mu \mathrm{m}$ (Fig. 2).

\section{Type II - Fusiform neurons with lateral dendrites}

This type of neuron was also detected in the shell. A thick lateral dendrite leaves the elongated (spindle) soma, usually in the middle part of the soma. The fusiform neuron with lateral dendrites showed a high intensity and expression of the GAD67 immunoreactive granules, which were extended to the beginning of the primary dendrite. The dimensions of the soma of this type of neuron are as follows: Dmax $22.51 \pm$ $3.12 \mu \mathrm{m}$ and Dmin $12.27 \pm 0.8 \mu \mathrm{m}$ (Fig. 3).

\section{Type III - Pyramidal neurons}

This type of neuron has a triangular soma, which varies from clearly pyramidal to an elongated pyramid. The pyramidal type of neuron is dominantly observed in the core of the nuclei. One of the dominant characteristics of this type of neuron is the presence of a strong apical dendrite, while the two basal dendrites are of a smaller diameter. The pyramidal type of neuron showed a high intensity and expression of the GAD67 immunoreactivity granules. The dimensions of this type of soma are as follows: Dmax 21.92 $\pm 3.2 \mu \mathrm{m}$ and Dmin $14.28 \pm 1.1 \mu \mathrm{m}$ (Fig. 4).

\section{Type IV - Multipolar neurons}

The multipolar neuron was one of the most dominant medium spiny neurons of the nucleus accumbens. Approximately six (from 3-8) primary dendrites rose from the different soma forms. The multipolar type of neurons showed a high intensity expression of the GAD67 immu-
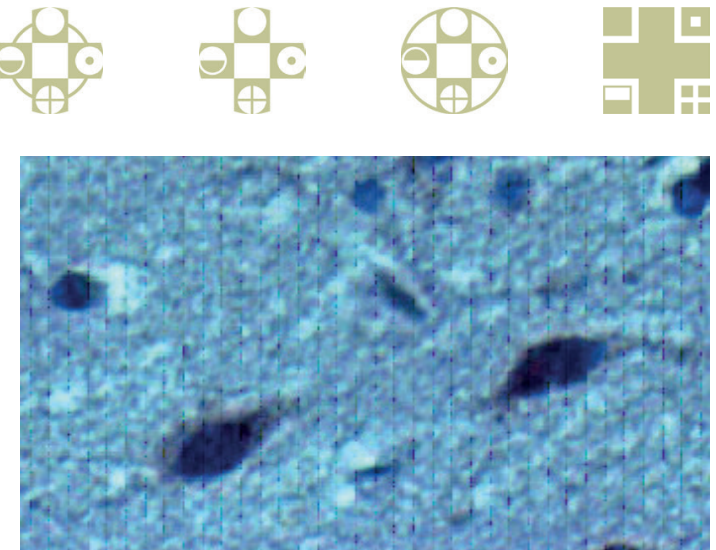

Fig. 2. The expression of GAD67 in fusiform medium spiny neurons of the human nucleus accumbens, $x 400$ magnification

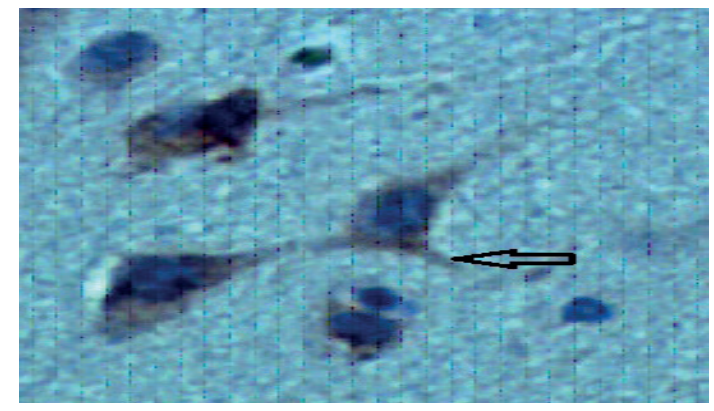

Fig. 3. The expression of GAD67 in fusiform medium spiny neurons with lateral dendrites of the human nucleus accumbens; the arrow indicates the lateral dendrite, $x 400$ magnification

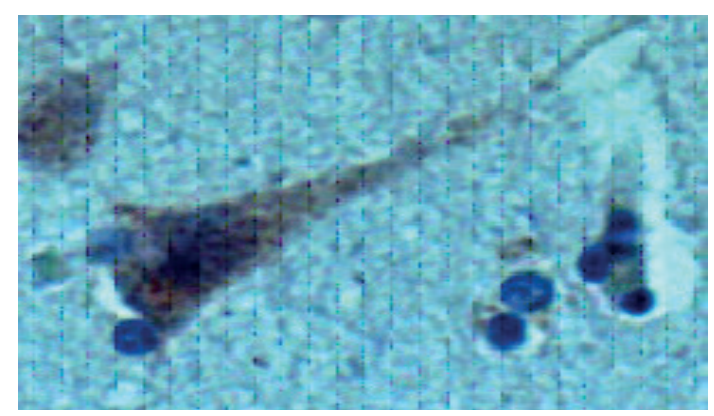

Fig. 4. The expression of GAD67 in pyramidal medium spiny neurons of the human nucleus accumbens, $x 400$ magnification

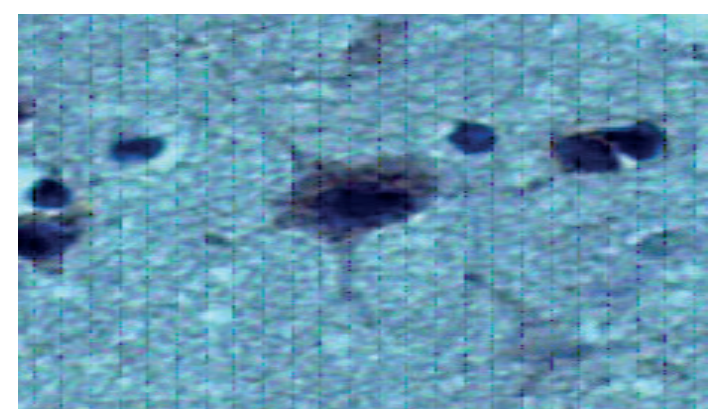

Fig. 5. The expression of GAD67 in multipolar medium spiny neurons of the human nucleus accumbens, $x 400 \mathrm{mag}$ nification 
noreactive granules. This type of neuron was predominantly registered in the core. The dimensions of this type of soma are as follows: Dmax $22.73 \pm 3.1 \mu \mathrm{m}$ and Dmin $15.23 \pm 1.3 \mu \mathrm{m}$ (Fig. 5).

\section{DISCUSSION}

The nucleus accumbens is a critical brain region involved in many reward-related behaviours. This nucleus comprises major compartments, including the core and the shell, which encompass several subterritories. GABAergic medium spiny neurons constitute the output neurons of the nucleus accumbens core and shell (24).

Drugs of abuse exert potent molecular and cellular alterations in the nucleus accumbens, and many of these changes occur in the medium spiny neurons, the principal projection neurons of the nucleus accumbens, which account for 90-95\% of all of the neurons in these regions (25).

Bolam et al. (26) used two methods, Golgi-Cox and immunohistochemistry, to identify two types of rat striatal medium spiny neurons, small and large. They found a strong GABAergic expression in the soma and primary dendrites in the major group of the medium spiny neurons.

In our study, we found 4 types of neurons that expressed GAD67 in the soma and, mainly, in the primary dendrites. In our previous morphological investigations (using the Golgi-Cox method), we found 4 types of medium spiny neurons in the human nucleus accumbens (3), which correlate to the immunohistochemical staining method used here.

The findings of animal studies of the GAD-immunoreactive neurons in the rat septum show that the soma of the medium spiny neurons had an oval, fusiform, pyramidal or multipolar shape. These types of neurons of the rat striatum (mostly medium spiny) show an intense expression of GAD67 that is localized in the soma and primary dendrites (27-30).

Trifonov et al (31) also found expression of GAD67 predominantly in the medium spiny neurons of the striatal region in rodents that were mainly of an oval soma shape.

Investigating the GABAergic expression of the rat striatal medium spiny neurons, Cuzon Carlson at al (32) found two morphological types. The first type had an oval soma shape, and the second type had a fusiform soma shape. The oval soma shape could be related to our type III and type IV neurons, while the fusiform neurons from their study could correlate with type I and type II neurons described in our study.

\section{CONCLUSION}

In our previous studies, we investigated the morphology of the medium spiny neurons of the human nucleus accumbens (soma shape, dendritic arborization, spines, axonal orientation, and diameter) using the Golgi-Cox method (3). Furthermore, we were interested in the mor- phology of the GABAergic medium spiny neurons based on the immunohistochemical expression of GAD67, an enzyme important in the synthesis of this major inhibitory neurotransmitter. Four types of medium spiny neurons of the human nucleus accumbens (fusiform, fusiform with lateral dendrites, pyramidal and multipolar), localized in both compartments of the nucleus core and shell, could be distinguished, and they morphologically correlate with those described by the Golgi study.

The significance of this study is to gain better insight into the basic morphology of the human nucleus accumbens, which completes the morphological and immunohistochemical profile of the limbic system.

\section{Acknowledgments}

This paper was written within the project JP-06 that was funded by the Faculty of Medical Sciences at the University of Kragujevac, Republic of Serbia.

\section{REFERENCES}

1. Záborszky L, Alheid GF, Beinfeld MC, Eiden LE, Heimer L, Palkovits M. Cholecystokinin innervation of the ventral striatum: a morphological and radioimmunological study. Neuroscience 1985;14:427-53;

2. Zahm DS, Brog JS. On the significance of subterritories in the "accumbens" part of the rat ventral striatum. Neuroscience 1992;50:751-67;

3. Sazdanović M, Sazdanović P, Zivanović-Macuzić I, Jakovljević V, Jeremić D, Peljto A, Tosevski J. Neurons of human nucleus accumbens. Vojnosanit Pregl 2011;68:655-60;

4. Cassella SN, Hemmerle AM, Lundgren KH, Kyser TL, Ahlbrand R, Bronson SL, Richtand NM, Seroogy KB. Maternal immune activation alters glutamic acid decarboxylase-67 expression in the brains of adult rat offspring. Schizophr Res 2016;171:195-9;

5. Kanjhan R, Noakes PG, Bellingham MC. Emerging Roles of Filopodia and Dendritic Spines in Motoneuron Plasticity during Development and Disease. Neural Plast 2016;2016:3423267;

6. Kalivas PW, Duffy PJ. D1 receptors modulate glutamate transmission in the ventral tegmental area. J Neurosci 1995;15:5379-5388; http://www.jneurosci.org/ content/15/7/5379.long

7. Reynolds SM, Berridge KC. Positive and negative motivation in nucleus accumbens shell: bivalent rostrocaudal gradients for GABA-elicited eating, taste "liking"/"disliking" reactions, place preference/avoidance, and fear. J Neurosci 2002;22:7308-20; http://www. jneurosci.org/content/22/16/7308.full.pdf+html

8. Sesack SR, Grace AA. Cortico-Basal Ganglia reward network: microcircuitry. Neuropsychopharmacology 2010;35:27-47; 
9. D’Souza MS. Glutamatergic transmission in drug reward: implications for drug addiction. Front Neurosci 2015;9:404;doi:10.3389/fnins.2015.00404

10. Mavridis I. The role of the nucleus accumbens in psychiatric disorders Psychiatriki 2015;25:282-94;

11. Meredith GE, Pennartz CM, Groenewegen HJ. The cellular framework for chemical signalling in the nucleus accumbens. Prog Brain Res 1993;99:3-24;

12. Langendorf CG, Tuck KL, Key T., Trevor LG. Key, Gustavo Fenalti,Pike RN., Rosado CJ., Anders SM. Wong, Ashley MB., Ruby HP. Law, andWhisstock JC. Structural characterization of the mechanism through which human glutamic acid decarboxylase auto-activates. \#Biosci Rep 2013;33:137-44;

13. Kalkman HO, Loetscher E. GAD(67): the link between the GABA-deficit hypothesis and the dopaminergic and glutamatergic theories of psychosis. J Neural Transm 2003;110:803-12;

14. Kalkman HO, Loetscher E, Akbarian S. Molecular and cellular mechanisms of altered GAD1/GAD67 expression in schizophrenia and related disorders. Brain Res Rev 2006;52:293-304;

15. Zhang X, Tong HL, Xiong X, Qiang C, Davidson C, Wetsel WC, Ellinwood EH. Methamphetamine induces long-term changes in GABAA receptor a2 subunit and GAD67 expression. Biochem Biophys Res Commun 2006;351:300-5;

16. Akbarian S, Huang HS. Molecular and cellular mechanisms of altered GAD1/GAD67 expression in schizophrenia and related disorders. Brain Res Rev 2006;293:30-4;

17. Dickerson DD, Overeem KA, Wolf AR , Williams JM, Abraham WC, Bilkey DK. Association of aberrant neural synchrony and altered GAD67 expression following exposure to maternal immune activation, a risk factor for schizophrenia. Transl Psychiatry 2014;4:418;

18. Denta G, Choic DC, Hermanc JP, Seymour L . GABAergic circuits and the stress hyporesponsive period in the rat: Ontogeny of glutamic acid decarboxylase (GAD) 67 mRNA expression in limbic-hypothalamic stress pathways. Brain Res 2007;1138:1-9;

19. Awapara J, Landua AJ, Fuerst R. Distribution of free amino acids and related substances in organs of the rat. Biochem Biophys Acta 1950;5:457-62;

20. Erlander MG, Tobin AJ. The structural and functional heterogeneity of glutamic acid decarboxylase: a review. Neurochem Res 1991;16:215-26;

21. Kaufman DL, Houser CR, Tobin AJ. Two forms of the gamma-aminobutyric acid synthetic enzyme glutamate decarboxylase have distinct intraneuronal distributions and cofactor interactions. J Neurochem 1991;56:720-3;

22. Martin DL, Rimvall K. Regulation of gamma-aminobutyric acid synthesis in the brain. J Neurochem 1993;60:395-407;

23. Meredith GE, Ypma P, Zahm DS. Effects of Dopamine Depletion on the Morphology of Medium Spiny Neurons in the Shell and Core of the Rat Nucleus Accumbens. J Neurosci 1995;15:3808-20;

24. Gangarossa G, Espallergues J, de Kerchove d'Exaerde A, Mestikawy SE, Gerfen CR, Hervé D, Girault JA, Valjent E. Distribution and compartmental organization of GABAergic medium-sized spiny neurons in the mouse nucleus accumbens. Front Neural Circuits 2013;19:7-22;

25. Lobo MK, Nestler EJ. The Striatal Balancing Act in Drug Addiction: Distinct Roles of Direct and Indirect Pathway Medium Spiny Neurons. Front Neuroanat 2011;5:41;

26. Bolam JP, Powel JF, Wu JY, Smith AD. Glutamate decarboxylase-immunoreactive structures in the rat neostriatum: a correlated light and electron microscopic study including a combination of Golgi impregnation with immunocytochemistry. J Comp Neurol 1985;237:1-20;

27. Onteniente B, Tago H, Kimura H, Maeda T. Distribution of gamma-aminobutyric acid-immunoreactive neurons in the septal region of the rat brain. J Comp Neurol 1986;248:422-30;

28. Köhler C, Chan-Palay V. Distribution of gamma aminobutyric acid containing neurons and terminals in the septal area. An immunohistochemical study using antibodies to glutamic acid decarboxylase in the rat brain. Anat Embryol (Berl) 1983;167:53-65;

29. Panula P, Revuelta AV, Cheney DL, Wu JY, Costa E. An immunohistochemical study on the location of GABAergic neurons in rat septum. J Comp Neurol 1984;222:69-80;

30. Kita H, Kitai ST. Glutamate decarboxylase immunoreactive neurons in rat neostriatum: their morphological types and populations. Brain Res 1988;447:346-52;

31. Trifonov S, Houtani T, Kase M, Toida K, Maruyama M, Yamashita Y, Shimizu JI, Sugimoto T. Lateral regions of the rodent striatum reveal elevated glutamate decarboxylase 1 mRNA expression in medium-sized projection neurons. Eur J Neurosci 2012;35:711-22;

32. Cuzon Carlson VC, Mathur BN, Davis MI, Lovinger DM. Subsets of Spiny Striosomal Striatal Neurons Revealed in the Gad1-GFP BAC Transgenic Mouse. Basal Ganglia 2011;1:201-11; 


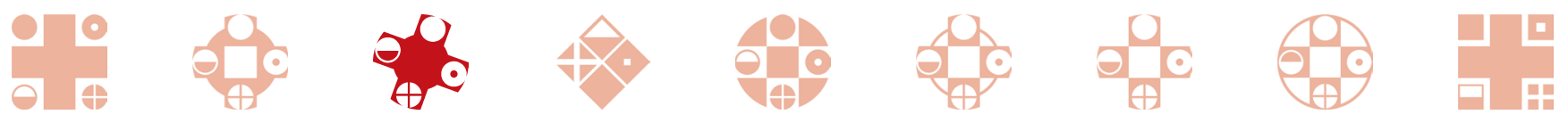

